\title{
QUANTITATIVE ECONOMIC HISTORY
}

N.F.R. Crafts

Number: 48/99

January 1999 

Working Paper No. 48/99

\section{Quantitative Economic History}

N.F.R. Crafts

(1) N.F.R. Crafts

Department of Economic History

London School of Economics

January 1999 


\author{
N.F.R. Crafts, \\ Department of Economic History, \\ London School of Economics, \\ Houghton Street, \\ London. WC2A 2AE.
}

\begin{tabular}{|c|c|}
\hline Telephone: & $+44(0) 1719556399$ \\
\hline Fax: & $+44(0) 1719557730$ \\
\hline E-mail: & n.crafts@Ise.ac.uk \\
\hline
\end{tabular}

Additional copies of this working paper are available at a cost of $£ 2.50$. Cheques should be made payable to 'Department of Economic History, LSE' and sent to the Economic History Department Secretary, LSE, Houghton Street, London. WC2A 2AE, U.K. 


\begin{abstract}
The paper provides a selective survey of applications of economics and econometrics in economic history focusing especially on the themes of living standards and technological change. Cliometric research in these areas is shown to have made major contributions to knowledge. It is argued that quantitative economic history is distinctive from applied economics and that modelling must be sensitive to historical context. Research prospects are exciting both because progress in economic theory has increasingly allowed the formalization and quantification of important arguments put forward by economic historians and also because important opportunities for cliometric research continually arise from contemporary economic concerns.
\end{abstract}

JEL Classification: I31; N01; N30; O33; O47.

Keywords: cliometrics; living standards; technological change. 


\section{Introduction}

Forty years on from the beginnings of the cliometric school in economic history, there is a vast literature that could be reviewed under the general subject area of this paper. Inevitably the coverage in this paper must be highly selective. I have chosen to emphasize research on big themes, namely, understanding technological change and measurement of living standards, which loom larger in economic history than in economics generally. These are also areas where the approach and focus of economic historians differs in important respects from that of everyday economics. I stress, in particular, the important implications of investigating the very long run and, before turning to specific issues relating to my chosen themes, consider explicitly what is special about research in quantitative economic history compared with the applied economics of the present.

In a review of early work in the field McCloskey correctly asserted that "economic theory, especially the theory of price, is the defining skill of cliometricians...A cliometrician is an economist applying economic theory (usually simple) to historical facts (not always quantitative) in the interest of history (not economics)" (1978, p. 15). This description is in every respect less apposite today than it was twenty years ago. Nevertheless, it has continued to be the case that there is often an excellent payoff to the straightforward application of techniques encountered in basic training in economics and quantitative methods.

In an earlier survey article, I distinguished five types of contribution that economics might make to economic history (Crafts, 1987). These categories - a) more facts; b) better facts; c) better hypotheses; d) better interpretation of the data; e) better historians - are still a useful starting point and can help in the evaluation of some of the specific achievements of the cliometric school attempted below. In each of these aspects, exemplars related to the key themes of later sections and showing the power of relatively elementary economic analysis can readily be found. 
The most prominent example of 'more facts' is the retrospective use of national income accounting on historical data to create estimates of real GDP for a core group of OECD economies stretching well back into the nineteenth century. Many individual research studies have been synthesized to create a dataset measured in purchasing power adjusted dollars of 1990 in the widely used work of Maddison (1995). The provision of 'better facts' has been associated especially with addressing index number problems better. Here, the biggest single breakthrough came with the work of Harley (1982) who transformed the literature on the British industrial revolution by showing that, when appropriate methods of weighting were adopted, index numbers of the volume of industrial production indicated that growth in the economy as a whole (rather than in a few atypical sectors) had actually been quite modest rather than reflecting a take-off as proclaimed by Rostow (1960).

One of the key skills of the economist in approaching an empirical task lies in formulating good hypotheses and using them to decide which pieces of information to collect. Fogel has rightly argued that it is "when hypotheses are treated as aids in the search for evidence, rather than as substitutes for it, they provide effective instruments of research ... much of what is often called hypothesis testing in 'scientific' history... is really the last step of hypothesis formulation" (1982, p. 106, 110). An excellent case in point relates to the celebrated debate from the early days of new economic history concerning the extent of 'entrepreneurial failure' in the pre-1914 British economy. Use of the basic tools of neoclassical economics cast the argument explicitly in terms of profit-maximization and thus highlighted the need to consider technical choices in the context of relative factor prices; British entrepreneurs were then shown to have been generally, though not always, rational in their rejection of American technologies which were unprofitable in British cost conditions (Sandberg, 1981). 
Better interpretation of data typically revolves around specifying ceteris paribus conditions where it might be expected that theory can play a valuable role, although not without incurring some downside risks. A good illustration of the importance of this occurs in the evaluation of comparative growth performance where neoclassical analysis will suggest the need to normalize for initial levels of capital intensity and total factor productivity and thus for transitory components in the growth process. Thus, while the raw data shows that British growth has been slower since the 1970 s than in the early postwar 'Golden Age', on a normalized basis, performance seems to have improved (Bean and Crafts, 1996).

The suggestion that use of economics might produce 'better historians' might seem both arrogant and misplaced. Much of the following section will, in effect, be devoted to seeking to justify this claim, provided that economics is used as an aid to historical reasoning rather than to colonize historians' thought processes. Perhaps the simplest yet most powerful examples of this come from the notion of 'additionality' which was central to much early work in cliometrics and which is fundamental to neoclassical economics. Thus, in calculating the social savings (performing an historical cost-benefit analysis) of nineteenth century American railroads, Fogel (1964) destroyed the myth of their indispensability by showing that for many purposes water transport was an excellent substitute such that the cost reduction attributable to the new technology was quite modest. But quantifying additionality requires a specification of the anti-monde; this is natural to economists' thinking but alien to many historians' basic training which stresses establishing the facts rather than speculating about what might have happened. Highlighting the potential - while also promoting greater awareness of the pitfalls - of counterfactual historical analysis is one of the most important ways in which better economic history can result from sensitive applications of modelling in economic history.

These illustrations support McCloskey's proposition that much progress in cliometrics has come from the application of quite basic ideas from economics. At 
the same time, it should be recognized that this generalization cannot bear too much weight. This is for two reasons. First, important results have also increasingly come from the use of high-powered quantitative methods and econometric techniques. For example, the most spectacular addition to the data available for longrun analysis of the British economy is the construction of estimates for the English population at 5year intervals back to 1541 , over 250 years prior to the first census, using highly sophisticated, computerized back projection techniques and a sample of parish registers (Wrigley and Schofield, 1981). Exploitation of the long runs of data that history provides has advanced rapidly as time series econometrics has developed and package programmes facilitating methods of analysis not yet developed fifteen years ago have become available, as is illustrated by the work of Mills and Crafts (1996) on British industrialization. Another important development, where sophisticated technique is central and where package programmes have made enormous strides, is the use of computable general equilibrium models. This is likely to be of increasing importance in analyzing the international economy and has already borne important fruit in the area of catch-up and convergence in the pre-1914 world economy (O'Rourke and Williamson, 1994, 1995).

Second, as economics has advanced in its ability to formalize previously intractable aspects of the real world, relating for example to economies of scale and imperfect competition, the theory which was relied on by early cliometricians may increasingly be challenged as both too restrictive and possibly quite misleading, particularly for the analysis of major economic events and/or long run implications of economic change. This is a central theme of the following section.

\section{What is Special about Quantitative Economic History?}

Quantitative economic history is rather more than simply the applied economics of the past. In part, this is because many of the most interesting problems are attached to a well-developed historiography and the audience to be persuaded comprises, in 
addition to economists, historians who do not necessarily share the same priors. Historians are unlikely to be convinced by econometric estimates alone; they require assurance of the intuitive reasonableness of regression results and the corroboration of other forms of evidence. Applied economists, by contrast, tend to place much higher weight than historians on constructing explanations and deriving predictions from formal models based on conventional microeconomic foundations that allow explicit interpretation of estimated coefficients. They would prefer to be precisely wrong rather than loosely right and attach relatively little importance to what they dismiss as 'anecdotal evidence'.

Many of the most interesting differences between economic history and applied economics have traditionally stemmed from the focus of the former on analysis of the long run. At a minimum, this puts a premium on constructing statistical databases and understanding the provenance and limitations of data sources. More to the point, however, the big issues of economic history have always revolved around addressing questions such as 'how did the West grow rich?' which create the need for careful measurement of changes in living standards and necessarily place technological change centre stage. Three implications of this focus on long-run economic development deserve to be noticed.

First, index number problems loom much larger in economic history than in everyday economics. Partly this comes from the sheer magnitude of changes in the structure of the economy and the range and quality of goods and services produced over several centuries. It is also, however, because economic historians are concerned at least as much with discussing living standards as production. This implies the need to take account of aspects of well-being that are not captured by conventional measures of real wages or real GDP such as changes in leisure, longevity and legal status. In turn, this raises obvious questions about how to deal with aggregation problems and/or to make imputations to growth rates. 
Second, it is less obvious that the marginal equivalences of neoclassical economics were achieved in the past (McClelland, 1975, p. 125). For example, it has been argued in some quarters that, prior to the twentieth century, English labour markets were dominated by custom such that money wages and wage differentials between different grades of labour were very inflexible (Phelps-Brown, 1977). Perhaps the most important illustration of this problem comes from the European demographic transition from relatively high 'natural' fertility to much smaller family sizes where birth control was widely used. This took place between 1870 and 1940 without depending on breakthroughs in contraceptive technology (Watkins, 1986). Watkins and other demographers tend to see fertility as essentially unrelated to neoclassical optimizing behaviour prior to the twentieth century and there certainly exists no satisfactory household economics explanation for the onset of rapid fertility decline.

Third, in their approach to long run economic development, economic historians have always wished to treat more variables as endogenous than would be usual in applied economics. For example, the development of well-defined and enforceable property rights has always been regarded as playing an important role in promoting the industrial revolution in western Europe and economic historians like North and Thomas (1973) have tried to explain differences in property rights by economic factors. Even more fundamentally, economic historians have always tended to treat innovation and sometimes invention as endogenous even when this was not the case in mainstream growth economics. The well-known controversy provoked by the claim in Habakkuk (1962) that differences in the rate and bias of technological change in nineteenth century Britain and America stemmed from differences in factor endowments epitomizes this point.

In the context of a focus on the very long run in economic history, it is interesting explicitly to consider the role of counterfactuals in the cliometric literature. Clearly, willingness to entertain counterfactuals is fundamental to weighing the relative importance of different explanatory variables. Fishlow (1974) made a useful 
distinction in this regard between what he called 'latently factual' and 'hypothetical' history. Thus, using regression estimates of a demand curve to predict the impact of higher cotton prices during the American Civil War on quantity of cotton consumed is plainly more reasonable than conjecturing on what the American economy in 1860 would have looked like had slavery never existed. In the former case, we are relatively confident that we can specify an acceptable model that will produce unbiased predictions with a small standard error whereas in the latter case we are not.

More generally, it should be recognized that economics does not supply lawlike statements for use in economic history. Estimated equations come with error terms and the causal relationships that we rely on typically come in the form probably if a set of factors then the predicted outcome. When specification of the counterfactual involves several of these probabilistic relationships, then our degree of confidence will be low. Thus, it tends to be harder to discuss situations where more factors are variable - long run general equilibrium results will be less reliable than those based on short run partial equilibrium. In some cases, there may be no well-specified theory to draw upon. For example, explaining the timing of the first Industrial Revolution turns on explaining the arrival of a few spectacular 'macroinventions', defined by Mokyr (1993, p. 22) as "those in which a radical new idea...emerges more or less ab nihilo", a task for which even the advent of endogenous innovation models leaves us ill-equipped (Crafts, 1995).

It seems even to be the case that trends in economic analysis are making quasilawlike statements harder to come by and this may imply that some of the early work in new economic history now needs to be revisited. The last twenty years has seen the arrival of new industrial economics, new international economics, the new economic geography, new growth economics and the much greater use of game theory in economics. As a result, old generalizations about the implications of industrial concentration for price-cost margins, the superiority of free trade, the 
unimportance of linkage effects and the independence of longrun growth from the investment rate have all been challenged. Game theoretic analyses frequently encounter multiple Nash equilibria and in real world cases we cannot rule out the possibility that players may well take actions that do not correspond to equilibrium play at all (Kreps, 1990, ch. 6). Some of these developments in economic modelling make possible the investigation of economic effects that have long been postulated by economic historians but have previously tended to be ignored by economists and cliometricians because they were not susceptible of formal treatment.

An interesting case in point is Fogel's celebrated study of the impact of the railroad in nineteenth century America. He found that the social savings from this transport innovation, based on a conventional analysis of the cost reduction for the volume of goods actually transported by rail, amounted to 4.7 per cent of GDP in 1890 . He regarded this as an upper bound measure because a zero price elasticity of demand for transport services was employed and, since the upper bound measure was small, felt justified in arguing that railways were not vital for American economic growth (1964, p.234). The model was not designed to deal with other important issues such as impacts on the spatial location of economic activity, the demand for industrial output, induced changes in rates of growth of factor inputs etc. However, since it is well known that with perfect competition and constant returns to scale, the standard cost-benefit analysis of the social savings captures all the static benefits and since with a traditional neoclassical model growth is independent of the savings rate, the conventional economics of the 1960s would have justified the limited attention given to such matters in the study. Historians expressed some unease that backward and forward linkage effects were dismissed rather too quickly (O'Brien, 1977, p. 68, 81) but there was no prospect of adequate modelling of such impacts in the 1960s.

Work in the new economic geography both undermines these assumptions and also has progressed to the point where the modelling of linkage effects makes sense and is feasible because computable general equilibrium models embracing scale 
economies and imperfect competition are now available. This means that a wide array of indirect impacts on demand and cost conditions in the transport using sectors can be encompassed and that it is recognized that direct benefits will be understated because price may exceed marginal cost in the transport using sector. Venables and Gasiorek (1998) have recently constructed a calibrated model of this kind which allows for a more integrated market to reduce price-cost margins, to promote exit and entry among firms and to permit economies of scale and agglomeration effects. They find that for freight traffic the ratio of benefits to those captured by orthodox cost-benefit analyses may be in the range 1.4 to 1.65 .

Similarly, research in the new growth economics also suggests that the benefits estimate obtained by Fogel may not be an upper bound. Baldwin (1989) considered the case of the European Single Market, which might be thought to be analogous to a major transport project, and concluded that an endogenous innovation growth model would suggest growth rate effects through wider markets that would imply that the conventional static benefits estimate should be multiplied by about 5 to capture the present value of the dynamic benefits.

Taking these two points together suggest both that Fogel's claim that his social savings figure is an upper bound may not be correct and that the true social saving could be substantially greater than his estimate. This does not mean that the myth of indispensability of the railroads should be reinstated nor that the discipline of trying to identify additionality should be discarded but it does suggest both that the search for evidence of the effects of railways may have been restricted by the priors used by many early cliometricians and that the non-railways counterfactual is very sensitive to the assumptions used which reflect trends in economic analysis rather than lawlike statements.

Indeed, considering the interest that economic historians have always shown in endogenizing technological change and in discussing long run economic change, it is 
striking that the models used in early cliometric work typically exclude or ignore the possibility of induced effects on growth of the kind now widely discussed in new growth economics. This is well reflected in the work on the British industrial revolution by well-known scholars such as Engerman (1972) on the role of the slave trade and Mokyr (1977) on the role of demand and the contributors of the chapters in the first edition of the new economic history textbook edited by Floud and McCloskey (1981).

The most striking example of an 'exogenous growth' approach in a major debate in economic history is probably the paper by McCloskey (1970) which seeks to deny that there was a growth failure in late Victorian Britain despite its being overtaken by the United States and rapidly caught up by other rivals while critics alleged that British technological performance was very weak (Landes, 1969). On the contrary, argued McCloskey, the British economy "was growing as rapidly as permitted by the growth of its resources and the effective exploitation of the available technology" (1970, p. 451). These conclusions were based on three very neoclassical arguments rather than a thorough perusal of the evidence. First, using a traditional Solow type growth model, it was argued that a higher home investment rate would not have raised the long run growth rate. Second, the highly competitive market environment was seen as precluding entrepreneurial failure. Third, the overall rate of total factor productivity (TFP) growth was taken to be exogenously determined.

While McCloskey's basic conclusions on growth failure may be broadly correct, as will be suggested below in section 4 , the point to be noted here is the heavy use of a priori reasoning (lawlike statements) that is no substitute for a careful review of the evidence once an endogenous growth approach is allowed. Thus, it might now be argued that TFP growth would reflect the allocation of resources to innovative activity and thus be influenced by (broad) capital accumulation strategies and market size, that competition and openness have ambiguous effects on innovation and that 'social capability' will influence the amount of technology transfer rather than 
relying on the universal technology assumption of traditional neoclassical growth economics.

Economic history without counterfactuals, whether implicit or explicit, will be no more than tedious description. The use of economic models in economic history makes counterfactual reasoning explicit and potentially allows quantification of claims of proximate causality and as such can make an enormous contribution to the quality of historical analysis. The danger is, however, that the truth of restrictive models is assumed and used as a way of dismissing arguments that deserve to be taken seriously in an historical context where a rich variety of induced effects may operate in the long run.

\section{Living Standards in Economic History}

Both development economists and economic historians have become increasingly concerned to develop measures of living standards that are more comprehensive than real wages or real GDP per head. Partly, this is because attention has increasingly turned to the lives that people lead rather than the incomes that they enjoy and partly because in most circumstances a substantial element of well-being is derived not on the basis of personal command over resources but depends on provision by the state - this tends to be true of health and education in many countries and is universally the case for civil and political rights (Dasgupta and Weale, 1992).

Studies of industrialization, in particular, have underlined to economic historians the possibility that there may be circumstances where material prosperity increases while other aspects of living standards such as life expectancy deteriorate (Engerman, 1997). It has long been recognized that industrialization in nineteenth century conditions, at least for most workers, implied that there was a trade-off between higher wages and a worse environment (Williamson, 1990). Moreover, research in historical demography has emphasized that over the last century or so 
changes in life expectancy have been largely independent of those in real incomes (Preston, 1975). Although traditionally economic historians have spent much of their effort in seeking to quantify real wages, increasingly this is seen as only part of what is required.

If changes in living standards are to be quantified, this is an area where index number problems are liable to be acute. Not only is appropriate measurement of the cost of living required, which we know from present concerns is difficult as new goods proliferate and quality improves over time (Shapiro and Wilcox, 1996), but weights have to be developed for the various components of a broad concept of economic welfare. In addition, some important aspects of well-being may not lend themselves readily to cardinal measurement.

What then are the options open to someone who is dissatisfied with conventional measures of real incomes in an historical context? Four approaches seem worth review, each of which has featured in the recent historical literature - these are heights, the Human Development Index (HDI), the Quality of Life Index and imputations to GDP growth. While using any of these may be problematic both conceptually and in terms of data requirements, it will be argued that that they do offer something useful by way of supplementing existing income measures and do tend to confirm that real wages and/or real GDP are not the whole story.

Since the late 1970s one of the most substantial research efforts in cliometrics has been devoted to investigation of human heights in the past. This has involved laborious compilation of data especially from military records and the development of appropriate statistical methods to deal with the truncated distributions that these often report (Wachter and Trussell, 1982). The potential value of height in the context of measuring living standards is that it is known to reflect nutritional status and to be sensitive to aspects that are not captured by real wages such as work effort 
and the disease environment to which a person is exposed (Steckel, 1995). Moreover, data on height are sometimes available when the conventional income measures are not.

In fact, there seem to be two different strands of thought about the value of research on heights among researchers in the area. At times, height appears to be suggested as a good index of welfare per se (e.g., Floud et al. 1990, p. 19) while at other times it is proposed as a good diagnostic in a particular historical situation that national income or real wages are failing to measure changes in welfare very well (e.g., Steckel, 1992, p.294). Unfortunately, there are serious difficulties in the use of heights as a proxy for living standards and the latter appears to be much the more defensible position.

It is essential to remember that attained height is potentially sensitive to relative price effects. Changes in relative prices as economic development proceeds and moves by the representative agent to a higher indifference curve could easily be associated with a fall in height, for example, because the relative price of food had increased or real wages had increased in big cities but not in rural districts. While information on stature could in principle be used to adjust national accounts concepts of income to reflect a broader measure of economic welfare, in practice the information requirements are severe and certainly exceed our current knowledge in at least two fundamental respects. First, we would need to devise a way of avoiding double-counting of the impact on height of expenditures already included in GDP and, second, we would need to find a way of quantifying the welfare implications of changes in height. More precisely, we would have to be able to estimate willingness to pay for non-private income influences on height since height per se is not an argument in the utility function (Steckel, 1995, pp. 1917-1919).

[Insert Table 1] 
This seems to leave only the second, diagnostic role at present but that may nevertheless be important, as Table 1 suggests. Declines in heights during the nineteenth century are reported there for several countries. In both the American and British cases, it has been suggested that the heights data indicate that economic growth and rising real wages are to some extent misleading indicators of changes in living standards. Having said this, it is not yet clear what exactly the diagnostic is picking up and thus what are the welfare implications. It could be costs of urbanization in terms of exposure of workers adverse urban disease environments (Floud et al. 1990) or increased inequality of incomes, as regression results obtained in Steckel (1983) might imply, or a reduction in food consumption in response to a rise in its relative price as argued by Komlos (1995).

The HDI devised under the auspices of the United Nations is described and refined in successive issues of the Human Development Report. Its focus is the escape from poverty and this is seen as depending on public services as well as private incomes. HDI is a composite of three basic components: longevity, knowledge and income. Human development is seen as a process of expanding people's choices; income is assumed to impact on this primarily at low levels of material well-being and, above a threshold level, it is considered to make a sharply diminishing contribution eventually tailing off to nothing. Longevity, measured by life expectancy at birth $\left(e_{0}\right)$, and knowledge, measured by a weighted average of literacy (LIT) and school enrolment (ENROL), are regarded as central to the enhancement of capabilities but are not closely correlated with or strictly dependent on private income. The components are combined in a single index by measuring them in terms of the distance travelled between the minimum and maximum values ever observed and averaging these scores into one index. The precise formula is noted in Table 2.

HDI has been somewhat controversial but has a wide appeal because of its emphasis on a broad concept of well-being including but going beyond income. Economic historians have begun to embrace the concept; in the words of Floud and Harris 
"there is a strong case for using ... the HDI to investigate the level of human welfare in the past" (1997, p. 114) while Costa and Steckel regard HDI as "a retrospective index of welfare...relevant for understanding the past ...the HDI measures how far an economy has come along the path to modern living standards" (1997, pp.73-74). Historical estimates of HDI or close approximations to it are possible back to the early nineteenth century in some countries and estimates have started to appear, some of which are reported in Table 2.

Nevertheless, the HDI has obvious weaknesses as a measure of economic welfare which may not yet be fully appreciated by economic historians. In common with heights, the approach runs into difficulties with weighting. It is possible in this case to calculate the implicit set of weights that it embodies but when this is done their justification is obscure, they vary dramatically at different income levels and are quite sensitive to the choice of extreme values. The very low weight given to income above an arbitrary threshold level is particularly hard for many commentators to accept (Gormely, 1995). Moreover, if the basic rationale of the index stems from a concern with capabilities and with the impact of social arrangements, then the coverage of HDI might well be regarded as too narrow. Despite these reservations about HDI, it may be valuable in historical research. Certainly, comparing today's developing countries with their European predecessors on the basis of HDI gives a quite different impression from that which is obtained using national accounts, as is reflected in the estimates for India and Italy in Table 2.

\section{[Insert Table 2]}

Indeed the results contained in Table 2 underline at least one important message. It is clear that any index of living standards giving a substantial weight to life expectancy will make the developing countries of the recent past look much better compared with the leading countries of 1870 than does a comparison based simply on real GDP/head. Moreover, since it is generally agreed that the majority of 
improvements in mortality experience have resulted from 'exogenous' factors such as advances in science and public health programmes, it is also likely that growth of living standards since 1870 as measured by real national income per head is a substantial underestimate. To confirm this, however, we would need a way to value the exogenous change in life expectancy in terms of income and the HDI methodology does not provide a way to carry this out.

Dasgupta and Weale (1992) stress that the HDI ignores other important aspects of well-being which depend on state provision rather than private income. In particular, they argue for the inclusion of civil and political rights in a more comprehensive Quality of Life Index. This raises two formidable problems: how to measure rights and how to incorporate them in an index with other components of welfare. Dasgupta and Weale, looking at evidence from the post 1970 period, proceeded as follows. They used a ranking scale of 1 to 7 to measure rights based on the survey data published in Taylor and Jodice (1983) which adopted a concept of civil rights based on freedom of the press and independence of the judiciary and a concept of political rights based on political liberty and the ability to vote governments out of office in free and fair elections. Political and civil rights are two of the six components in the Quality of Life index, the others being income per head, adult literacy, life expectancy and infant mortality. Dasgupta and Weale's solution to the index number problem was to use ordinal aggregation based on the Borda Rule. In other words, each observation was ranked on each criterion and these ranks were then summed to find the Borda score.

An ordinal approach of this kind has many merits and deserves serious consideration by economic historians in future. In principle, it is very flexible and other arguments can be included or weighting schemes introduced within the aggregation procedure. This weakens somewhat the criticisms that might be made of the inclusion of the rights measures, namely, that they are ethnocentric and subjective judgements would be needed to generate similar rankings for earlier periods. Nevertheless, if this index 
is claimed to have general applicability, then the most promising justification is on the grounds that certain 'prudential' values comprise a core set that is shared by all persons and, if so, it is not clear that this list of six aspects is acceptable (Qizilbash, 1997). For those who dislike the equal weights embodied in the basic Borda Rule, Qizilbash suggests two options. Either to look for Pareto Dominance or to experiment with weights while retaining all the arguments and see whether overall rankings are sensitive to weighting (intersection Borda ranking). Unfortunately, it seems likely that in the most interesting cases, where historians will disagree, these procedures are unlikely to resolve the argument.

None of the three methodologies discussed so far allows for conventional economic growth rates to be adjusted to accommodate a broader concept of the standard of living, although this has been attempted in the past, most notably by Nordhaus and Tobin (1972). Usher (1980, ch. 7) provides a detailed rationale for making imputations to growth rates for environmental changes, i.e., for variables that contribute to welfare, are not counted directly or indirectly as part of income and where the average amount enjoyed is changing over time. He argues that in these cases it is only the value of changes to consumption that should be taken into account. Usher takes pollution, crime, life expectancy and leisure to be potentially important examples. All are clearly relevant to a long run view of living standards and probably should eventually be addressed by economic historians but only the last two have been quantified thus far. Even in these cases the results are no more than preliminary and the assumptions/data requirements are rather demanding.

The adjustment to real GDP growth suggested by Usher (1980) for changes in mortality is as follows 
$\Delta \mathrm{Q} / \mathrm{Q}=\Delta \mathrm{Y} / \mathrm{Y}+(\Delta \mathrm{E} / \mathrm{E}) / \beta$

where Q is GDP adjusted for mortality changes, $\mathrm{E}$ is an age-structure weighted average of discounted life expectancies and $\beta$ is the elasticity of annual utility with respect to annual consumption. In this formula an increase in mortality is treated as a completely exogenous change in the consumers' environment which cannot be bought but for which a price would willingly be paid. A more general formulation suggested by Williamson (1984) for use in historical circumstances where, for example, nutritional improvements may be part of the story is

$\Delta \mathrm{Q} / \mathrm{Q}=\Delta \mathrm{Y} / \mathrm{Y}+(\mathrm{z} \Delta \mathrm{E} / \mathrm{E}) / \beta$

where $\mathrm{z}$ is the proportion of mortality change taken to be exogenous. It is not easy to find firm historical evidence on appropriate values of the discount rate, $z$ and $\beta$, although for late nineteenth century Europe values around 5 per cent, 0.75 and 0.25 respectively may be about right (Crafts, 1997a). Williamson's formula is used to produce the imputations for mortality reported in Table 3 .

Nordhaus and Tobin (1972) found that their attempt to estimate the long run rate of growth of 'Measurable Economic Welfare' (MEW) for the United States was totally dominated by adjustments for leisure/non-market work time. This is noteworthy for three reasons. First, leisure has been ignored in all the recent work on living standards. Second, how best to handle time use in measuring living standards is highly controversial; while Usher (1980) argued that it is best treated as an environmental variable, he recognized that others might prefer to see it as a regular commodity, in which case the total value of hours not spent in market work needs to 
be added to income. The environmental assumption valuing changes tends to raise measure growth rates for OECD countries while the commodity assumption tends to do the opposite unless leisure time is assumed to have increasing productivity. Third, an assumption needs to be made as to whether there is technological progress in the enjoyment of leisure and/or performance of non-market work.

Given these difficulties, it is perhaps not surprising that most economists have chosen to avoid the issue. For economic historians, however, this does not seem to be acceptable because, as Nordhaus and Tobin (1972) discovered, changes in market work time over the long run have been very large indeed. Maddison (1995) suggests that average hours worked per person employed per year in OECD countries were close to 3000 in 1870 whereas in recent years they have been little more than half that. Changes in age structure and labour force participation rates over time have also been pronounced but a fairly similar proportionate change has occurred in hours worked per member of the population. The potential imputation to conventionally measured growth is clearly large, as Table 3 shows, where the imputation is on the basis of valuing changes in market work time at the average wage rate in the terminal year and adding this amount to end year GDP and assuming no technological progress in time use.

[Insert Table 3]

Obviously, the calculations in Table 3 are at best crude approximations and they rely on some strong assumptions. The main point that they make is simply that imputations along these lines tend to be rather large and suggest that conventional GDP growth rates understate the rate of improvement of average living standards for reasons that would be familiar to devotees of both the HDI and the MEW. Indeed, since the estimates rely on a rather conservative assumption of zero productivity growth in non-market work time, these imputations may well be rather too low. 
A good way to pull together some of the points made in this section is to ask what difference it might make to take these various ideas from economics and apply them to the classic debate on the standard of living of the working classes during the British industrial revolution. This is a controversy that has already had a substantial input from cliometrics which has significantly improved both the database about which arguments can be made and also the economic development context in which different strands of the debate should be understood.

Much of the effort from cliometricians has gone into improving conventional estimates of real wages and national income growth during the industrial revolution. In each case, better index numbers have been the key contribution. In the case of macroeconomic growth, the most important development has been the production of improved weightings for industrial production (Crafts and Harley, 1992). For real wages a great deal of effort has gone into the production of better cost of living indices (Lindert and Williamson, 1983; Crafts and Mills, 1994; Feinstein, 1995). In addition, diligent analysis of budget studies has also produced a good deal more information on earnings of family members other than male heads of household (Horrell and Humphries, 1992).

There are too many data problems to reach complete agreement and existing cost of living indices, while much better designed, still offer quite a wide range of estimates. It is agreed that real wage growth was slow, especially before 1820 and that by 1850 there are clear signs of an improvement in average real wages compared with 1780 . In turn, the context for this is now generally accepted to be that the acceleration of economic growth during the industrial revolution was more modest than previous estimates had suggested and that growth of real output per head was very slow at least until the 1820 s in the face of demographic pressure. The general tendency of this debate has been that, for the average worker, any gains in living standards before 1820 are very doubtful but between 1820 and 1850 there are unambiguous signs of improvement (Lindert, 1994). 
What difference would it make to approach the controversy with the broader indices of living standards discussed above? Table 4 sets out evidence on trends in components of well-being and reports some of the new index numbers. The central feature of Table 4, which underlines why the episode has been controversial, is the disparate movement of the various components of living standards. For example, in the early years, while growth in income is at best very modest, life expectancy improves but civil rights deteriorate. After 1830, income grew more quickly and civil rights improve markedly but mortality conditions worsen.

Turning to the indices, the weights of the HDI would summarize the evidence in more optimistic terms than confining attention to real wages. This conclusion holds, although less strongly, for variants of the HDI that have been suggested in the Human Development Report, namely the GDI (the gender-related development index), which takes account of disparities between men and women and employs a gender inequality aversion coefficient, and the DAHDI (the distribution adjusted HDI) in which the income variable is multiplied by (1 - Gini). The Dasgupta and Weale Quality of Life Index also exhibits steady improvement with each year showing an improvement in rank. While it has often been supposed that looking at the overall quality of life would be more supportive of pessimistic views on living standards than confining attention to real wages, these results reject that view.

An investigator who used heights as an index of welfare would come to a very different conclusion, namely that there was a period of falling living standards and that it came when real wages at last showed definite gains, between 1830 and 1850 , at a time when the improvement in life expectancy was checked. One reaction to this conflict between heights and the HDI or Quality of Life indices would be to say that this underlines the unsuitability of heights as an index of living standards and to 
consider it as a diagnostic, perhaps on the basis of a detailed look at disaggregated patterns of changes in heights.

Further analysis of the components of the Quality of Life index shows that there is some evidence of Pareto Dominance such that 1850 dominates 1760 and 1780 and that 1830 dominates 1760,1780 and 1820. Experiments with alternative weighting schemes found that, on intersection Borda ranking, 1830 is superior to 1800,1850 is superior to 1820 and 1820 is superior to 1760 . Any judgement on 1830 compared with 1850 turns out to be very sensitive to the weights given to infant mortality and life expectancy.

The detailed evidence presented by Floud et al. (1990) established that the decline in heights is an urban phenomenon intensified by the rapid urbanization of the economy. Recent research has also suggested that during the second quarter of the nineteenth century, mortality in big British cities deteriorated (Szreter and Mooney, 1998), and in turn the solution to this problem seems to have awaited adequate public health interventions and supply of local public goods (Szreter, 1997). Heights and the detailed analysis of the Quality of Life index both seem to argue that Britain was characterized by a market failure of the kind highlighted by the capabilities approach but overlooked in computations of real wages and also to suggest that the optimistic assessment of living standards in the second quarter of the nineteenth century needs reconsideration.

It may, however, not be appropriate to stop here without further quantification. Williamson (1990) has strenuously argued on the basis of econometric analysis of wage variations across towns that the wage gains made by urban workers far outweighed the disamenities payments that they required to accept worse environmental conditions. Using the imputations approach to consider the impact of changing mortality, modest additions to GDP growth of around 0.2 per cent per year would apply during 1760 to 1830 with a subtraction of a similar amount per year 
during $1830-50$, a result that tends to support Williamson's inference that there were net living standards gains in that period.

Once again, it is also worth remarking that changes in time use appear to be the forgotten aspect of standards of living in the industrial revolution as well as more recently. Here the evidence is still very thin but some progress has been made using court records to establish changing patterns of daily behaviour. A tentative result from this work is that the early stages of the industrial revolution through to the beginnings of the nineteenth century may have seen quite a big increase in average hours of market work per worker per year. Voth (1998) estimates that London area workers averaged 2631 hours in 1760 but 3366 in 1800. An imputation for this, using Usher's methodology as before, might subtract about 0.3 per cent per year from growth during 1760-1800.

Overall, the main outcomes of this exercise are first to show that it is possible to use the new tools for measurement of living standards to illuminate a classic historical debate, second, to emphasize the value of going beyond real wages in assessing the contribution of the industrial revolution to the quality of life, and thirdly, to demonstrate that the existing textbook summaries of the state of play need considerable qualification. On the other hand, it certainly should not be claimed that this additional quantification has resolved the debate.

\section{Catch-Up, Convergence and All That}

In the early days of the new economic history the principal tools for the formal analysis of growth were the Solow growth model, the aggregate, well-behaved production function and growth accounting based on these concepts. This provided, and still provides, useful discipline and helpful benchmarks for the historical understanding of growth around the basic relationship: 
$\Delta \mathrm{Y} / \mathrm{Y}=\alpha \Delta \mathrm{K} / \mathrm{K}+\beta \Delta \mathrm{L} / \mathrm{L}+$ TFPgrowth

where $\alpha+\beta=1$. In particular, the insights that this model provides based on diminishing returns to accumulating more and more identical capital, that growth in the long run is independent of the investment rate, that growth will tend to be inversely related to the initial level of capital (and income) per worker and to exhibit catch-up through reductions in factor intensity gaps between countries, and that many aspects of institutions or economic policy thought by the general public to affect growth may only have levels effects, are valuable.

Nevertheless, the traditional neoclassical model plainly also has severe limitations, especially for explaining long run growth. Two of the most obvious are the failure to distinguish human capital as a separate factor of production and the treatment of TFP growth as exogenous. Two slightly less obvious are the temptation to identify the Solow residual with technological change and the implied treatment of catch-up and overtaking that are embodied in the model.

A response to one of these criticisms was to switch to the Augmented-Solow model which adds human capital to the factors of production while retaining the wellbehaved production function and exogenous TFP growth. thus equation (3) becomes:

$$
\Delta \mathrm{Y} / \mathrm{Y}=\alpha \Delta \mathrm{K} / \mathrm{K}+\beta \Delta \mathrm{L} / \mathrm{L}+\gamma \Delta \mathrm{H} / \mathrm{H}+\text { TFP growth }
$$

where $\mathrm{H}$ is human capital and $(\alpha+\beta+\gamma=1)$. Given that in equilibrium $\mathrm{H} / \mathrm{K}$ will be a constant ratio, the Augmented Solow model has broadly similar properties to the Solow model provided $(\alpha+\gamma)<1$ but transitional convergence to the steady state will be more gradual. This model with common technology in all countries has 
been argued to provide a good explanation of income levels in international crosssections and an acceptable way to account for recent growth experience (Mankiw et al. 1992) and it lies behind the more sophisticated analysis of conditional convergence in Barro (1997). Nevertheless, a closer look at the data even for the OECD countries suggests that a number of implications of the Augmented-Solow model are invalid and this should restrain economic historians' enthusiasm for it.

First, tests based on time-series econometric methods have rejected both the strong form of convergence that long term forecasts of differences in output per person for OECD countries tend to zero and also the weaker version that long run forecasts of output per person are proportional with a single long term trend for all advanced countries (Bernard and Durlauf, 1995; Mills and Crafts, 1999). Second, Prescott (1998) concluded after a lengthy review of the evidence that the neoclassical growth model with or without human capital cannot explain international income differences which are so large that the hypothesis of common TFP across countries must be rejected. Similarly, Islam (1995) re-examined the Mankiw et al (1992) results using a panel data approach and found that country specific differences in TFP were substantial. None of this will be surprising to economic historians like Clark (1987) who found huge productivity differences in cotton textiles across countries on the eve of World War I long after the technology used in the industry had become generally and well-known.

Third, Milbourne (1995) estimated the following regression for eighteen OECD countries in 1960-1985:

$\ln \left(y_{\mathrm{t}} / \mathrm{y}_{0}\right)^{1 / \pi}=$ Constant $+\beta_{1} \operatorname{lns} \mathrm{s}_{\mathrm{k}}+\beta_{2} \ln \mathrm{s}_{\mathrm{h}}+\beta_{3} \ln (\mathrm{n}+\mathrm{g}+\delta)+\lambda_{1} \mathrm{y}_{0}+\lambda_{2} \ln \mathrm{A}_{0}$

which is derived from the Augmented Solow model where y is income per worker, $\mathrm{s}_{\mathrm{k}}$ and $\mathrm{s}_{\mathrm{h}}$ are the physical and human capital savings rates, $\mathrm{n}$ is population growth, $\mathrm{g}$ 
is the rate of technological progress, $\delta$ is the depreciation rate and $\mathrm{A}$ is the level of technology. If the Augmented-Solow specification is correct, then $\left(\lambda_{1}+\lambda_{2}\right)=0$. This restriction is easily rejected. This implies that the initial level of TFP affects subsequent income growth rather than simply the initial factor intensities. Thus, contraction of labour productivity gaps between leaders and followers in OECD growth has involved not only reducing the factor shortfalls in human and physical capital per worker, as envisaged by the Augmented-Solow model, but also reducing TFP gaps. Indeed, Milbourne's estimates suggest that these two aspects of catch-up growth were of a similar magnitude.

The most influential economic historian writing on the topic of catch-up in economic growth attributes the variability of experience and TFP performance that is not readily captured by the Augmented Solow model to 'social capability' (Abramovitz, 1986). This is not tightly defined but a number of important ingredients are indicated. The basic idea is that countries differ in their ability effectively to assimilate technology. A major step forward in the analysis of the historical experience of growth would come if this notion could be pinned down more precisely and quantified.

One aspect of 'social capability' that can be identified is human capital, not as a factor of production, but as a determinant of the speed and completeness of technological catch-up in follower countries. This formulation is in fact supported by the econometric results in Benhabib and Spiegel (1994) and Islam (1995). Social capability clearly involves much more than education, however, and Abramovitz himself stressed the role of institutions and the incentive structures to which they give rise. At one level, this involves the prevalence of rent-seeking and the ability of vested interests to thwart modernization of the economy rather as argued by Prescott (1998). More fundamentally, the appropriation of profits is central to efforts to reduce costs through innovation and technology transfer. A key requirement is that 
transactions costs are kept reasonably low and that entrepreneurs are not deterred from investing in fixed costs by opportunism and 'hold-up' problems.

In accounting for long run growth we need to acknowledge the role of technological change and, in general, would wish to endogenize TFP growth rather than leave it as exogenous or seek to suppress it as in some recent endogenous growth models. Economic historians generally will be supportive of Romer in his suggestion that ideas gaps matter as well as object gaps in explaining income differences across countries and will applaud his statement that "our knowledge of economic history, of what production looked like 100 years ago, and of current events convinces us beyond any doubt that discovery, invention and innovation are of overwhelming importance in economic growth ... We could produce statistical evidence suggesting that all growth came from capital accumulation with no room for anything called technological change. But we would not believe it." (Romer, 1993, p. 562)

Perhaps then, economic historians will find more use for the recent endogenous innovation models of growth set out in Grossman and Helpman (1991) or Aghion and Howitt (1997) which might be said to have quite close links with the idea of social capability. In essence, this approach accepts the insights of the neoclassical growth model with regard to the relationship between physical capital and growth and, as with equation (3), predicts that in the long run growth rate will be proportional to TFP growth. The difference lies in the model's prediction that TFP growth will depend on the resources used in innovative activity which depends in turn on the expected ability to appropriate profits from innovation. In the GrossmanHelpman model, innovation and growth depend positively on the size of the market, the productivity of labour in research, and the degree of market power. In Aghion and Howitt, imperfect competition is central to profit-motivated innovation but monopoly is expected to be bad for growth because it encourages managers to enjoy a quiet life. 
The central insight of the endogenous innovation models that is valuable for economic historians is that expected profitability of innovative activity can influence the long run growth rate. There is plenty of evidence in the technology literature to support the centrality of the appropriability of returns to innovative effort and the role of market size in supporting R \& D (Jaffe, 1988) but the detailed assumptions in the early endogenous innovation literature, for example with regard to the importance of monopoly power and patents are not supported. Lead times over rivals seem in most cases to be the key imperfection in competition (Levin et al. 1987) and, in line with Aghion and Howitt, rivalry among big firms seems to be helpful in stimulating R \& D (Patel and Pavitt, 1992).

Taking a wider view of the appropriability problem, it is clear that 'hold-up' problems will potentially inhibit innovative effort and, thus, growth. This opens up a link to a wide array of arguments about growth familiar from the historical literature, for example in relation to the role of property rights and strong but limited government (Weingast, 1995). Many institutional arrangements might influence the seriousness of hold-up problems. For example, an illustration relating to industrial relations can be found in Bean and Crafts (1996), where it is argued that multiple unionism in postwar British industry inhibited productivity improvement because neither reputation not contractual mechanisms could commit workers not to expropriate innovators ex post. In sum, it is probably the spirit rather than the letter of these new growth models that should be taken on board by economic historians and which might be useful in exploring social capability more deeply.

Catching-up is not automatic and history suggests that absence of social capability may be a crucial obstacle to growth and development. Gerschenkron (1962) provided a famous discussion of the opportunities and difficulties of 'economic backwardness' of which modern economics can help make more sense. Insights from Gerschenkron's analysis may still be helpful in understanding both why 
institutions and sources of growth differ in later developers and the difficulties which may emerge following a period of rapid catch-up while substantial productivity gaps still remain.

Gerschenkron suggested that backward countries could achieve a take-off into very rapid growth if they could substitute for 'missing prerequisities', in particular a lack of 'entrepreneurship'. Gerschenkron's arguments can be restated as proposing that institutional innovations to establish larger vertically integrated enterprises, to develop investment banking, to provide strong cash flows for incumbent producers and to allow a strong role for the state in the allocation of investment offer a route to rapid catch-up growth. This might be regarded as very much the same thing as establishing social capability through reducing transactions costs and problems arising from asymmetric information plus solving co-ordination problems.

It follows that, in Gerschenkron's view, the optimal boundaries of the firm, methods of corporate governance and design of capital markets may vary at different stages of development as may the priority given to mobilizing savings as opposed to achieving an optimal allocation of resources. If this is so, a distinct possibility is that, at some point, the original institutional arrangements become sub-optimal or even dysfunctional but hard to modernize. For example, at some stage, more orthodox Western financial systems may become superior but, where bankers and regulators lack the relevant human capital and resources, switching may be fraught with problems of moral hazard. Alternatively, interest groups may be able successfully to lobby against change. It is important to recognize that neither Gerschenkron's arguments nor the conditions under which the proposed development trajectory would be able to resist rent-seeking or crony capitalism and be capable eventually of efficient metamorphosis have yet been given solid microconomic foundations, although developments in economic theory since he wrote suggest that this might be possible. 
These issues have new salience in the context of recent East Asian economic history. Strategies to achieve rapid growth bear a strong resemblance to Gerschenkron's recipe. Rodrik (1995) provides an account of the policies of Korea and Taiwan for mobilizing investment that matches the above description fairly closely. Moreover, the well-known 'getting relative prices wrong' and 'governed markets' approaches of, respectively, Amsden (1989) and Wade (1990) to explaining fast growth in these countries can also be seen as having very strong similarities. The recent financial crises bear strong witness to the downside risks of financial liberalization despite the clear need to reform later on in the development process (Miller and Luangaram, 1998).

The main attempts to quantify these institutional aspects of social capability have come in recent work in the international cross-section growth regressions literature. Prominent examples of this work can be found in Barro (1997), Knack and Keefer (1995) and Mauro (1995). Each of these studies adds to a conventional cross section regression a variable that seeks to measure, respectively, the applicability of the rule of law, the security of property rights and contract enforcement, and the extent of corruption. In each case, large and significant effects are found which imply that low institutional quality is a serious drag on growth. The variables themselves are taken from survey evidence on country risks collected by agencies publishing information to inform investors. The implications of these 'second generation' growth regressions are that catch-up growth prospects are much less strong in countries like those of the former Soviet Union than would be supposed on the basis of looking just at their endowments of human capital and the large initial productivity gap (EBRD, 1997).

This suggests that the economic historians' preoccupation with social capability and warnings that catch-up is not automatic are probably justified but the work thus far may not adequately address the question of measurement, especially since the variables derived from the survey evidence have a fairly tenuous connection with the 
appropriation and transactions costs issues that lie at the heart of the new growth economics. For example, it is noticeable that both Italy and Korea score quite badly on several of these indicators and might in many ways be regarded as 'corrupt', yet, as Gerschenkron might have predicted, they have found ways to prevent opportunism undermining economic growth. Moreover, these data are only available for the recent past. Although there has been some welcome progress, therefore, quantification of social capability remains to be satisfactorily achieved.

Despite the advent of growth regressions, the single most important quantitative tool available for the historical analysis of growth remains growth accounting, at bottom using applications of equation (3). Its results should be seen more as benchmarks and explicanda than literal truths but nevertheless it provides an important quantitative framework for thinking about growth and is an important safeguard against explanations of growth based on wishful thinking and ahistorical theorizing especially those that are hyperbolic on the importance of technological revolutions. Thus, growth accounting estimates of TFP growth during the industrial revolutions in Britain (Crafts, 1995) and the United States (Abramovitz, and David, 1998) suggest only a modest contribution to growth throughout the nineteenth century.

Care is needed, however, in interpreting the results from growth accounting. It is important to recognize that the TFP estimates that it produces do not translate directly into estimates of the rate of technological change. A glance at Maddison (1996, p. 59) underlines this point as he offers a breakdown of TFP growth since 1950 in six OECD countries which distinguishes a foreign trade effect, a structural change effect, an economies of scale effect and a catch-up effect together with an unexplained component. The first three of these should probably be regarded as improvements in the allocation of resources rather than technological change.

Maddison's estimates are ad hoc, however, and it would be nice to approach the historical decomposition of TFP growth more formally. The work of Morrison 
(1993) provides a rigorous methodology for doing this which allows for the distorting effects of market power, scale economies and quasi-fixed factors/capacity utilization on conventional Solow residuals and then permits the estimation of 'true' technological change. Unfortunately, the data requirements for this technique are quite severe but it has been applied to Italy by Rossi and Toniolo (1991) (1996). They found that the component of Italian TFP growth attributable to technological change was only 0.1 out of 0.8 per cent per year in 1895-1939 and 0.5 per cent out of 3.0 per cent per year in 1950-90.

Another source of bias which will usually pull in the other direction and may be substantial has been stressed by Rodrik (1997), namely that TFP growth estimates from conventional growth accounting implicitly rely on the assumption either that technological change is neutral or that the elasticity of substitution between factors of production is one. Both these assumptions are probably false. In this case, however, we are unlikely to be able to quantify the bias accurately although we do know that it is more serious the faster is the rate of growth of capital inputs relative to labour inputs, which will typically occur during periods of rapid catch-up growth.

\section{[Insert Table 5]}

The most obvious example of the continued value of growth accounting is provided by recent work on growth in East Asia. Table 5 reports what are probably the best set of estimates for that region compiled on a comparable basis by Collins and Bosworth (1996). Their work is fairly representative, although difficulties of the data mean that further revisions may well emerge. For example, it is likely that Singaporean TFP growth is underestimated because of measurement errors relating to the capital stock and China's overestimated through output growth measurement errors. Table 5 also displays similar estimates for the fast catch-up phase of growth in Japan and some Western European countries which provide an interesting comparison. 
Contrary to earlier beliefs, the general point made by writers considering estimates like those of Table 5 is that East Asian growth has resulted much more from capital accumulation, based both on high savings rates and low capital to output ratios, than from productivity growth. To this should also be added the substantial contribution of demographic factors working through age structure changes leading to fast growth of labour inputs per person. This is a pronounced difference from Europe where the demographic transition long preceded the Golden Age. Together the Asian capital and labour contributions really do seem to dwarf those in their European counterparts whereas the fast growth of TFP in Europe, and also in early postwar Japan, makes recent Asian achievements somewhat disappointing.

The impression given by these estimates is that development strategies for escape from backwardness in East Asia were actually better at mobilizing resources than achieving rapid TFP growth which might well be what Gerschenkron would have predicted. In comparative perspective, that seems unlikely to be undermined by Rodrik's arguments on bias since capital deepening was even more pronounced in Golden Age Europe. Given the strong role probably played by factors other than technological progress in Europe's rapid TFP growth, it would, however, be wrong at this point to suggest that East Asia has been a failure at innovation per se, given both that institutional arrangements in the leading countries have been much praised for their success in encouraging technology transfer (Bell and Pavitt, 1993) and also that distortions in the allocation of investment funds appear likely to be a significant factor in retarding productivity growth (Lee, 1995; Smith, 1995). What is clearly needed is some quantitative analysis aimed at decomposition of TFP growth over time in different countries, techniques for which are now available, as was noted earlier.

[Insert Table 6] 
An obvious reaction to the growth accounting results is to be sceptical of them on the grounds that, until the recent financial crises, East Asian countries seemed to outperform their European rivals even including the leading countries that had already matched European income levels. Some sort of reality check seems to be required especially to persuade both historians and economists who dislike the specifcation of the production function on which the estimates rely. Table 6 offers some help and at the same time underlines the importance of theory in selecting appropriate comparisons from the data.

If productivity is the focus of attention in catch-up growth, then comparisons should be made in those terms rather than proxies such as GDP per person. The estimates in Table 6 indicate that, although East Asian countries have caught up Western Europe in terms of income per person, there is still a sizeable labour productivity gap. A greater proportion of people are in the working age groups in Asian countries and hours worked per year are typically a good deal longer than in Western Europe (Crafts, 1998a). Given that it seems clear that Asian capital per worker is higher relative to Europe than is output per worker, then the explanation for this remaining productivity gap must to a large extent result from lower TFP in Asia and there is still considerable scope for TFP catch-up, at which leading Asian countries may be improving (Collins and Bosworth, 1996). Thus, the paradox of fast growth at high income levels is resolved when productivity performance is analyzed in detail.

[Insert Table 7]

Growth accounting is an ingredient but does not of itself supply all the benchmarks that evaluation of comparative growth performance requires. We need some way to judge whether a country exceeded what might have been expected given its starting point. This clearly requires econometric modelling and there is no agreed way to do this but the economics literature offers some possibilities. Table 7 offers one simple 
exercise based on the work of Benhabib and Spiegel (1994). Their research implies that the TFP growth rate that might be expected during catching-up depends on the standard of education and the initial productivity gap and their regressions give an estimate of the magnitude. Based on this estimate, it appears that Golden Age Europe had unexpectedly rapid TFP growth while the opposite was true during Asia's recent catch-up. This adds weight to the suggestion that Asian countries have been better at mobilizing factor inputs and acquiring technology than in using resources efficiently but plainly needs supplementing by more sophisticated analyses.

Although there may be many reasons to argue about the detail of these growth accounting exercises and their extensions, nevertheless in sum they provide a strong antidote to many of the myths about Asian growth that are frequently believed. Similar value can often be had in economic history as has been confirmed by the long run studies of British and American economic growth of Matthews et al. (1983) and Abramovitz and David (1998).

Rather less explicit attention has been paid to overtaking by the new growth economics than to catch-up and convergence. This is unfortunate for economic historians because the long run growth process clearly has involved changing leadership, most famously at the point where the United States decisively overtook Britain in terms of real GDP per person and also became the world's undisputed technological leader at the end of the nineteenth century. By 1929, American real GDP per person was 131.4 per cent of the British level having been only 75.3 per cent in 1870 (Maddison, 1995). Again, Solow models leave something to be desired here. With common technology, savings rates and population growth we will see convergence but not overtaking and the historical experience in question clearly involves more than just differences in steady state income levels based on factor intensities, although ultimately the much higher level of natural resources per head in America does seem to have mattered. 
[Insert Table 8]

Endogenous growth theory certainly envisages the possibility of divergence and overtaking more readily than did traditional neoclassical theory. This is especially true if technological spillovers between countries are rather weak, a situation that seems more likely to have prevailed a century ago than now (Nelson and Wright, 1992), and either social capability or learning experiences differ across countries. In fact, explicit discussions of overtaking or leapfrogging tend to have been built on learning and can be thought of as modern versions of the dynamic consequences of comparative advantage. In this regard, it is striking that Table 8 reports huge differences in revealed comparative advantage in the US and the UK at the time when leadership changed. Broadly speaking American comparative advantage centred on sectors that were natural resource intensive and/or research intensive while British comparative advantage seems to have been based more on the expertise built up during the industrial revolution (Crafts, 1989; Wright, 1990).

The original learning models linking endogenous growth to comparative advantage were put forward in Krugman (1987) and Lucas (1988). Here sectorally specific learning which augments domestic human capital with no international spillovers potentially delivers both different long-run growth rates and reinforces the initial comparative advantage. An extension to provide leapfrogging in a Ricardian trade model is provided in Brezis et al. (1993) which can result in leapfrogging if the factor price incentives in the follower country encourage earlier adoption of and greater learning in a new technology with higher long run productivity potential. Lucas (1993) offers a different extension by exploring a situation where leadership can be sustained indefinitely but only if, through a succession of technologies, learning advantages spill over to new rapid learning sectors. 
These models and more mainstream endogenous innovation growth economics both have insights to offer that were absent from the early new economic history discussion of alleged Victorian failure and, in fact, may help to account for the emergence of much faster TFP growth in the United States after the turn of the century (Abramovitz and David, 1998) which fits rather uneasily with McCloskey's (1970) exoneration of British growth performance. Indeed, it might be the case that the case that Victorian Britain did not fail will ultimately rest on aspects that are excluded from traditional neoclassical growth models.

Mutatis mutandis, the learning models might be used to formalize the messages coming from research which has reformulated the Habakkuk hypothesis that American technological leadership stemmed from its factor endowments. Econometric research has established conclusively that technological change in American manufacturing was pervasively materials and capital-using and labour saving after 1850 (Cain and Paterson, 1986) and this in turn seems to have relied heavily on learning processes shaped by technical choices that responded both to cheap natural resources and a large and relatively homogeneous market, conditions that were not found in Europe at that time (Nelson and Wright, 1992). By the early twentieth century, the acceleration in American growth that moved the country decisively ahead of Britain can be explained at least in part by arguments familiar from endogenous innovation. Thus, the domestic market is far larger than that of Britain, American corporations have larger production runs, research labour is relatively cheaper and better trained than in Britain (Crafts, 1998b).

Nevertheless, the historical experience is much richer than either of these research streams can yet encompass. Williamson (1996) has pointed to the central role of factor migration in American economic growth as both labour and capital chased American natural resources. David and Wright (1997) have stressed both the importance of social capability in terms of effective property rights and the crucial role of feedbacks and increasing returns that eventually led to American resource 
abundance, rather than rapid resource depletion, through learning, discovery and induced human capital formation. Thus, both the size of the market and the natural resource endowments that distinguish America from Britain in the early twentieth century were endogenous rather than exogenous. On top of this, the greater size and standardization of the American market provoked important institutional innovations that facilitated the use of new technologies. For example, American employers had far greater incentives to undermine trade unionism and craft control in many industries, although not in sectors like construction and printing where market size and standardization were unimportant (Haydu, 1988).

Clearly, we do not yet have a good formal model that can do justice to this historical experience. Equally, however, we are a lot closer to having such a model than was true even fifteen years ago. The challenge here is formidable because economic historians wish to treat so much as endogenous and have a more subtle view of the mainsprings of technological change than is yet embraced by modern growth economics.

Nevertheless, the general message of this section is one of considerable progress in the range of useful models available for economic historians interested in growth and technological change and optimism about future prospects. If one were to construct what is hopefully a reasonably tractable wishlist for progress in this area, it would probably contain three key elements. First, that explicit attention be paid to the microeconomics of social capability with a view to developing more subtle measures of institutional differences between countries. Second, a related point, that the microeconomics of Gerschenkron's backwardness hypothesis are explored fully. Third, that the role of natural resources in economic growth is taken more seriously in models which consider induced effects on both institutional and technological change. 


\section{Concluding Comments}

The preceding two sections have attempted to demonstrate both the vitality and the increasing sophistication of quantitative economic history. Advances in economics and econometrics have enriched research in economic history and the field now has moved a long way beyond the early days chronicled by McCloskey (1978). At the same time, economic historians will do well to continue to resist mechanical and insensitive models that suppress key aspects of the past and ultimately impoverish historical research. Perhaps one of the most encouraging aspects of developments in economic modelling is that this is now less of a worry in many areas because of the increased subtlety of the economist's approach and the wider range of models that are available, for example, with regard to the ability to incorporate imperfect competition and asymmetric information in many situations where they used to be assumed away. There is every reason to believe that this progress should continue and that economics will continue to become more useful to economic history as it comes to terms with the complexities of economic life that were previously regarded as 'too difficult' to model. 
Table 1. Male Height, 1800-1950. (cm)

$\begin{array}{lllll} & 1800 & 1850 & 1900 & 1950 \\ \text { Australia } & & 172.7 & 170.9 & 173.8 \\ \text { France } & 163.7 & 164.7 & 166.6 & 172.3 \\ \text { Germany } & & 162.6 & 169 & 176.3 \\ \text { Japan } & 157.1 & 155 & 157 & 162 \\ \text { Netherlands } & 167.8 & 167.4 & 170.0 & 178.1 \\ \text { Sweden } & 167.0 & 168.2 & 172.5 & 177.9 \\ \text { UK } & 168.9 & 165.3 & 169.3 & 174.1 \\ \text { USA } & 172.9 & 171.1 & 170.0 & 177.1\end{array}$

Source: derived from Steckel and Floud (1997, Table 11.1); estimates refer to cohorts born in the year stated. 
Table 2. The Human Development Index, 1870 and 1973.

$\begin{array}{lllll}\text { GDP/Head } & \text { Life } & \text { Literacy } & \text { Enrolment } & \text { HDI } \\ \text { (\$1990int) } & \text { Expectancy } & (\%) & (\%) & \end{array}$

1870

France

1858

42.0

69

40.7

0.400

Germany

1913

36.2

80

41.6

0.397

Italy

1467

28.0

32

16.3

0.187

3263

41.3

76

35.4

0.496

USA

2457

44.0

75

0.466

1973

France

Germany

12940

72.4

97

43.8

0.466

Italy

13152

70.6

99

66.7

0.881

10409

72.1

94

0.876

UK

11992

72.0

99

0.862

16607

71.3

99

0.883

66.7

0.900

China

1186

63.2

27

34

0.407

India

853

50.3

77

0.289

65.0

64.2

28.1

0.547

Source: Crafts (1997a, Tables 1, 4 and 5).

The HDI is defined as follows:

$$
\begin{array}{ll}
\text { Life Expectancy }(\mathrm{L}) & =\left(\mathrm{e}_{0}-25\right) /(85-25) \\
\text { Schooling }(\mathrm{S}) & =0.67 \mathrm{LIT}+0.33 \mathrm{ENROL} \\
\text { Income }(\mathrm{I}) & =\left(\mathrm{Y}_{\text {adj }}-200\right) /(5385-200)
\end{array}
$$

Each of these components has a value between 0 and 1 as does HDI $=(L+S+I) / 3$.

Adjusted income is measured by the following formula which heavily discounts income above the threshold level, $\mathrm{y}^{*}=5120$ (\$1990int)

$$
\begin{array}{ll}
Y_{\text {adj }}=y^{*}+2\left[\left(y-y^{*}\right)^{1 / 2}\right] & \text { for } y^{*}<y<2 y^{*} \\
Y_{\text {adj }}=y^{*}+2\left[\left(y-y^{*}\right)^{1 / 2}\right]+3\left[\left(y-2 y^{*}\right)^{1 / 3}\right] & \text { for } 2 y^{*}<y<3 y^{*}
\end{array}
$$

and so on. $\$ 5385$ is an approximate maximum for this formula. 
Table 3. Growth Rates Adjusted for Changes in Mortality and Leisure (\% per year)

GDP/Head Mortality Mortality \& Leisure

1870-1913

France

Germany

Italy

UK

USA

1.5

1.9

2.2

2.2

1.6

2.1

2.1

2.4

2.5

1.8

1.0

1.8

1.1

1.8

1.1

1.6

1.5

2.4

2.2

1913-1950

Germany

Italy

UK

USA

0.8

0.8

1.6

1950-1973

France

Germany

Italy

UK

USA

4.0

5.0

5.0

2.5

2.4

1973-1992

France

1.7

Germany

2.1

Italy

UK

2.4

1.4

1.4

Source: Crafts (1997a, Table 7)

$\begin{array}{ll}4.5 & 5.4 \\ 5.3 & 6.1 \\ 5.6 & 5.9 \\ 2.8 & 3.2 \\ 2.6 & 2.9\end{array}$

2.2

3.0

$2.7 \quad 3.1$

$3.0 \quad 3.0$

$1.9 \quad 2.5$

$2.0 \quad 1.5$ 
Table 4. Living Standards in Industrial Revolution Britain

$\begin{array}{llllll}1760 & 1780 & 1800 & 1820 & 1830 & 1850\end{array}$

\section{Components}

$\begin{array}{lllllll}\text { Real GDP/Head } & 1803 & 1787 & 1936 & 2099 & 2209 & 2846 \\ \text { Life Expectancy } & 34.2 & 34.7 & 35.9 & 39.2 & 40.8 & 39.5 \\ \text { Infant Mortality } & 174 & 173 & 145 & 154 & 149 & 156 \\ \text { Literacy } & 48.5 & 49.5 & 52.5 & 54.5 & 57.5 & 61.5 \\ \text { Schooling } & 1.4 & 1.5 & 1.8 & 2.0 & 2.3 & 2.7 \\ \text { Political Rights } & 3 & 3 & 3 & 3 & 3 & 3 \\ \text { Civil Rights } & 3 & 3 & 4 & 4 & 3 & 1\end{array}$

Indices

$\begin{array}{lllllll}\text { Heights } & 167.4 & 168.0 & 168.9 & 170.7 & 170.7 & 165.3 \\ \text { HDI } & 0.272 & 0.277 & 0.302 & 0.337 & 0.361 & 0.407 \\ \text { Quality of Life } & 6 & 5 & 4 & 3 & 2 & 1 \\ \text { GDI } & 0.232 & 0.240 & 0.263 & 0.283 & 0.309 & 0.335 \\ \text { DAHDI } & 0.216 & & 0.238 & & & 0.307 / 0.321\end{array}$

Sources: based on Crafts (1997b) where details of the formulae for GDI and DAHDI are set out. HDI is calculated on an earlier version than that in Table 2 which uses years of schooling rather than enrolment. Real GDP/Head is in the 1990 international dollars employed by Maddison (1995). The rights variables are based on the concepts used by Dasgupta and Weale (1992) 
Table 5. Sources of Growth: Golden Age OECD vs Recent East Asia (\% per year)

$$
\text { Capital Labour TFP Output }
$$

1950-73

$\begin{array}{lllll}\text { France } & 1.6 & 0.3 & 3.1 & 5.0 \\ \text { Italy } & 1.6 & 0.2 & 3.2 & 5.0 \\ \text { Japan } & 3.1 & 2.5 & 3.6 & 9.2 \\ \text { UK } & 1.6 & 0.2 & 1.2 & 3.0 \\ \text { West Germany } & 2.2 & 0.5 & 3.3 & 6.0\end{array}$

1960-94

$\begin{array}{llllr}\text { China (1) } & 2.3 & 1.9 & 2.6 & 6.8 \\ \text { China (2) } & 4.0 & 2.1 & 4.6 & 10.7 \\ \text { Hong Kong } & 2.8 & 2.1 & 2.4 & 7.3 \\ \text { Indonesia } & 2.9 & 1.9 & 0.8 & 5.6 \\ \text { Korea } & 4.3 & 2.5 & 1.5 & 8.3 \\ \text { Malaysia } & 3.4 & 2.5 & 0.9 & 6.8 \\ \text { Philippines } & 2.1 & 2.1 & -0.4 & 3.8 \\ \text { Singapore } & 4.4 & 2.2 & 1.5 & 8.1 \\ \text { Taiwan } & 4.1 & 2.4 & 2.0 & 8.5 \\ \text { Thailand } & 3.7 & 2.0 & 1.8 & 7.5\end{array}$

Sources: Europe and Japan from Maddison (1996) except Italy from Rossi et al. (1992); East Asia derived from Collins and Bosworth (1996) except for Hong Kong which is based on Young (1995) with factor shares adjusted to match Collins and Bosworth's assumptions. China (1) is for 1960-1994; China (2) is for 1984-1994. 
Table 6. Real GDP/Person and Real GDP/Hour Worked, 1996 (\$1990 international)

$\begin{array}{lll} & \text { GDP/Person } & \text { GDP/Hour Worked } \\ \text { Norway } & 22256 & 32.46 \\ \text { Switzerland } & 20252 & 23.17 \\ \text { Denmark } & 19803 & 24.85 \\ \text { West Germany } & 19622 & 29.68 \\ \text { Netherlands } & 18504 & 31.26 \\ \text { France } & 18207 & 28.47 \\ \text { Austria } & 17951 & 24.76 \\ \text { Belgium } & 17756 & 29.84 \\ \text { Sweden } & 17566 & 25.35 \\ \text { UK } & 17326 & 22.68 \\ \text { Italy } & 16814 & 26.23 \\ \text { Finland } & 15864 & 21.67 \\ \text { Ireland } & 15820 & 25.43 \\ \text { Spain } & 13132 & 23.50 \\ \text { Portugal } & 12015 & 14.09 \\ \text { Greece } & 10950 & 17.08 \\ & & \\ \text { Hong Kong } & 21201 & 18.81 \\ \text { Singapore } & 20983 & 15.87 \\ \text { Japan } & 19582 & 20.06 \\ \text { Taiwan } & 14222 & 14.28 \\ \text { Korea } & 12874 & 11.70 \\ \text { Malaysia } & 7764 & \\ \text { Thailand } & 6112 & 4.51 \\ \text { China } & 4551 & 3.75 \\ \text { Indonesia } & 3464 & 2.87 \\ \text { Philippines } & 2369 & \end{array}$

Sources: GDP and population from Maddison (1995) (1997) and Asian Development Bank (1997); hours worked from Crafts (1998a). 
Table 7. Projected vs Actual TFP Growth (\% per year)

$$
\begin{aligned}
& \text { Years of } \\
& \text { Schooling }
\end{aligned}
$$

Gap

1.84

2.81

5.13

1.40

2.25
Projected

TFP Growth
Actual

TFP Growth

1950-73

$\begin{array}{lllll}\text { France } & 8.2 & 1.84 & 1.3 & 3.1 \\ \text { Italy } & 4.9 & 2.81 & 1.4 & 3.2 \\ \text { Japan } & 8.1 & 5.13 & 3.6 & 3.6 \\ \text { UK } & 9.4 & 1.40 & 1.1 & 1.2 \\ \text { West Germany } & 8.5 & 2.25 & 1.7 & 3.3\end{array}$

1960-84

China

Hong Kong

Indonesia

Korea

Malaysia

Philippines

Singapore

Taiwan

Thailand

\section{7}

5.2

1.1

3.2

2.3

3.8

3.0

3.2

3.5
12.75

3.48

9.90

8.60

5.74

7.52

5.62

8.00

10.88

\section{3}

1.8

2.1

3.1

1.7

3.0

2.0

2.9

4.2
1.8

2.4

0.8

1.5

0.9

$-0.4$

1.5

2.0

1.8

1984-94

China

Indonesia

Korea

Malaysia

Philippines

Singapore

Taiwan

Thailand

\section{6}

5.0

9.7

7.0

7.4

6.1

6.2

7.5
9.62

9.86

3.47

4.32

9.67

1.92

2.79

7.20
3.8

4.0

2.4

2.2

5.8

0.9

1.7

3.6
4.6

0.9

2.1

1.4

$-0.9$

3.1

2.8

3.3

Sources: Crafts (1998a); the weighting formula to derive column (3) is taken from Benhabib and Spiegel (1994) and Gap is defined as the ratio of the highest GDP/person to that of the country concerned in the initial year. 
Table 8. Revealed Comparative Advantage in American and British Manufacturing

\begin{tabular}{cccr}
\multicolumn{2}{c}{ UK Rankings } & \multicolumn{2}{c}{ USA Rankings } \\
1913 & 1929 & 1913 & 1929
\end{tabular}

$\begin{array}{lrrrr}\text { Agricultural Equipment } & 10 & 16 & 2 & 1 \\ \text { Cars and Aircraft } & 12 & 14 & 4 & 2 \\ \text { Non-Ferrous Meatls } & 16 & 13 & 1 & 3 \\ \text { Industrial equipment } & 5 & 8 & 3 & 4 \\ \text { Electricals } & 8 & 7 & 5 & 5 \\ \text { Books and Films } & 13 & 6 & 10 & 6 \\ \text { Metal Manufactures } & 7 & 11 & 6 & 7 \\ \text { Iron and Steel } & 3 & 4 & 9 & 8 \\ \text { Chemicals } & 11 & 10 & 12 & 9 \\ \text { Wood and Leather } & 15 & 15 & 7 & 10 \\ \text { Rail and Ship } & 1 & 1 & 8 & 11 \\ \text { Brick and Glass } & 14 & 12 & 11 & 12 \\ \text { Apparel } & 6 & 9 & 14 & 13 \\ \text { Fancy Goods } & 9 & 5 & 13 & 14 \\ \text { Alcohol and Tobacco } & 4 & 2 & 15 & 15 \\ \text { Textiles } & 2 & 3 & 16 & 16\end{array}$

Source: Crafts (1989); revealed comparative advantage is based on rankings of sectors by world market share where 1 is highest. 


\section{References}

Abramovitz, M. (1986), Catching-Up, Forging Ahead, and Falling Behind, Journal of Economic History, 36, n.2, pp. 385-406.

Abramovitz, M. and P. David (1998), American macroeconomic growth in the era of knowledge-based progress: the long-run perspective, in: S. L. Engerman and R. E. Gallmann (eds.), An Economic History of the United States, Cambridge, Cambridge University Press, forthcoming.

Aghion, P. and P. Howitt (1997), Endogenous Growth Theory, Cambridge, Mass., MIT Press.

Amsden, A. H. (1989), Asia's Next Giant, New York, Oxford University Press.

Asian Development Bank (1997), Asian Development Outlook 1997 and 1998, New York, Oxford University Press.

Baldwin, R. (1989), The Growth Effects of 1992, Economic Policy, 9, 248-281.

Barro, R. J. (1997), Determinants of Economic Growth, Cambridge, Mass., MIT Press.

Bean, C. and N. F. R. Crafts (1996), British economic growth since 1945: relative economic decline... and renaissance?, in: N. F. R. Crafts and G. Toniolo (eds.), Economic growth in Europe since 1945, Cambridge, Cambridge University Press, pp.131-172.

Bell, M. and K. Pavitt (1993), Technological Accumulation and Industrial Growth: Contrasts between Developed and Developing Countries, Industrial and Corporate Change, 2, n.2, pp. 157-210.

Benhabib, J. and M. M. Spiegel (1994), The Role of Human Capital in Economic Development: Evidence from Cross-Country Data, Journal of Monetary Economics, 34, n.2, pp. 143-173.

Bernard, A. B. and S. N. Durlauf (1995), Convergence in International Output, Journal of Applied Econometrics, 10, n.1, pp. 97-108.

Brezis, E. S., P. R. Krugman and D. Tsiddon (1993), Leapfrogging in International Competition: A Theory of Cycles in Technological Leadership, American Economic Review, 83, n.4, pp. 1211-1219. 
Cain, L. P. and D. G. Paterson (1986), Biased Technical Change, Scale and Factor Substitution in American Industry, 1850-1919, Journal of Economic History, 46, n.1, pp. 153-164.

Clark, G. (1987), Why Isn't the Whole World Developed? Lessons from the Cotton Mills, Journal of Economic History, 47, n.1, pp. 141-173.

Collins, S. M. and B. P. Bosworth (1996), Economic Growth in East Asia: Accumulation versus Assimilation, Brookings Papers on Economic Activity, 2, pp. 135-191.

Costa, D. L. and R. H. Steckel (1997), Long term trends in health, welfare, and economic growth in the United States, in: R. H. Steckel and R. Floud (eds.), Health and welfare during industrialization, Chicago, University of Chicago Press, pp. 4789 .

Crafts, N. F. R (1987), Economic history, in: J. Eatwell, M. Milgate and P. Newman (eds.), The New Palgrave: a dictionary of economic theory and doctrine, vol. 2, London, Macmillan, pp.37-42.

Crafts, N. F. R. (1989), Revealed Comparative Advantage in Manufacturing, 18991950, Journal of European Economic History, 18, n.1, pp. 127-137.

Crafts, N. F. R. (1995), Exogenous or Endogenous Growth: the Industrial Revolution Reconsidered, Journal of Economic History, 55, n.4, pp. 745-772.

Crafts, N. F. R. (1997a), The Human Development Index and Changes in Standards of Living: Some Historical Comparisons, European Review of Economic History, 1, n.3, pp. 299-322.

Crafts, N. F. R. (1997b), Some Dimensions of the 'Quality of Life' during the British Industrial Revolution, Economic History Review, 50, n.4, pp. 617-639.

Crafts, N. F. R. (1998a), East Asian growth before and after the crisis, in: IMF, Working Paper, n.98/137.

Crafts, N. F. R. (1998b), Forging Ahead and Falling Behind: The Rise and Relative Decline of the First Industrial Nation, Journal of Economic Perspectives, 12, n.2, pp. 193-210.

Crafts, N. F. R. and C. K. Harley (1992), Output Growth and the British Industrial Revolution: A Restatement of the Crafts-Harley View, Economic History Review, 45, n.4, pp. 703-730. 
Crafts, N. F. R. and T. C. Mills (1994), Trends in Real Wages in Britain, 17501913, Explorations in Economic History, 31, n.2, pp. 176-194.

Dasgupta, P. and M. Weale (1992), On Measuring the Quality of Life, World Development, 20, n.2, pp. 119-131.

David, P. and G. Wright, "Increasing Returns and the Genesis of American Resource Abundance, Industrial and Corporate Change, 6, n.2, pp. 203-245.

EBRD (1997), Transition Report, London.

Engerman, S. L. (1972), The Slave Trade and British Capital Formation in the Eighteenth Century: a Comment on the Williams Thesis, Business History Review, 46, n. 4 , pp. $430-443$.

Engerman, S. L. (1997), The standard of living debate in international perspective: measures and indicators, in: R. H. Steckel and R. Floud (eds.), Health and welfare during industrialization, Chicago, University of Chicago Press, pp. 17-45.

Feinstein, C. H. (1995), Changes in nominal wages, the cost of living and real wages in the United Kingdom over two centuries, 1780-1990, in:P. Scholliers and V. Zamagni (eds.), Labour's reward, Aldershot, Edward Elgar, pp. 3-36.

Fishlow, A. (1974), The New Economic History Revisited, Journal of European Economic History, 3, n.3, pp. 453-467.

Floud, R. and B. Harris (1997), Health, height, and welfare: Britain, 1700-1980, in: R. H. Steckel and R. Floud (eds.), Health and welfare during industrialization, Chicago, University of Chicago Press, pp. 91-126.

Floud, R. and D. N. McCloskey (eds.) (1981), The Economic History of Britain since 1700, vol. 1, Cambridge, Cambridge University Press.

Floud, R., K. W. Wachter and A. Gregory (1990), Health, Height and History, Cambridge, Cambridge University Press.

Fogel, R. W. (1964), Railroads and American Economic Growth: Essays in Econometric History, Baltimore, Johns Hopkins University Press.

Fogel, R. W. (1982), Circumstantial evidence in 'scientific' and traditional history, in: D. Carr et al. (eds.), Philosophy of history and contemporary historiography, Ottawa, University of Ottawa Press, pp. 
Gerschenkron, A. (1962), Economic Backwardness in Historical Perspective, Cambridge, Mass., Belknap Press.

Gormely, P. J. (1995), The Human Development Index in 1994: Impact of Income on Country Rank, Journal of Economic and Social Measurement, 21, n.3, pp. 253267.

Grossman, G. M. and E. Helpman (1991), Innovation and Growth in the Global Economy, Cambridge, Mass., MIT Press.

Habakkuk, H. J. (1962), American and British Technology in the Nineteenth Century, Cambridge, Cambridge University Press.

Harley, C. K. (1982), British Industrialization before 1841: Evidence of Slower Growth during the Industrial Revolution, Journal of Economic History, vol. 42, n.2, pp. 267-289.

Haydu, J. (1988), Employers, Unions and American Exceptionalism: Pre-World War I Open Shops in the Machine Trades in Comparative Perspective, International Journal of Social History, 33, n.1, pp. 25-41.

Horrell, S. and J. Humphries (1992), Old Questions, New Data, and Alternative Perspectives: Families' Living Standards during the Industrial Revolution, Journal of Economic History, 52, n.4, pp. 849-880.

Islam, N. (1995), Growth Empirics: A Panel Data Approach, Quarterly Journal of Economics, 110, n.4, pp. 1127-1170.

Jaffe, A. B. (1988), Demand and Supply Influences in R and D Intensity and Productivity Growth, Review of Economics and Statistics, 72, n.3, pp. 431-437.

Knack, S. and P. Keefer (1995), Institutions and Economic Performance: CrossCountry Tests using Alternative Institutional Measures, Economics and Politics, 7, n. 3, pp. 207-227.

Komlos, J. (1995), The Biological Standard of Living on Three Continents, Oxford, Westview Press.

Kreps, D. M. (1990), Game Theory and Economic Modelling, Oxford, Oxford University Press.

Krugman, P. (1987), The Narrow Moving Band, the Dutch Disease, and the Competitive Consequences of Mrs Thatcher, Journal of Development Economics, 27, n. 1 , pp. 41-55. 
Landes, D. S. (1969), The Unbound Prometheus, Cambridge, Cambridge University Press.

Lee, J-W (1995), Government Interventions and Productivity Growth in Korean Manufacturing Industries, National Bureau of Economic Research Working Paper, n. 5060 .

Levin, R. C., A. K. Klevonick, R. R. Nelson and S. G. Winter (1987), Appropriating the Returns from Industrial R \& D, Brookings Papers on Economic Activity, n.3, 783-820.

Lindert, P. H. (1994), Unequal living standards, in: R. Floud and D. McCloskey (eds.), The economic history of Britain since 1700, vol. 1, Cambridge, Cambridge University Press, pp.357-386.

Lindert, P. H. and J. G. Williamson, English Workers' Living Standards during the Industrial Revolution, Economic History Review, 36, n.1. 1-25.

Lucas, R. E. Jr. (1988), On the Mechanics of Economic Development, Journal of Monetary Economics, 22, n.1, pp. 3-42.

Lucas, R. E. Jr. (1993), Making a Miracle, Econometrica, 61, n.2, pp. 251-272.

McClelland, P. D. (1975), Causal Explanation and Model Building in History, Economics and the New Economic History, Ithaca, Cornell University Press.

McCloskey, D. N. (1970), Did Victorian Britain Fail?, Economic History Review, 23, n.3, pp. 446-459.

McCloskey, D. N. (1978), The Achievements of the Cliometric School, Journal of Economic History, vol 38, n. 1, pp. 13-28.

Maddison, A. (1995), Monitoring the World Economy, 1820-1992, Paris: OECD.

Maddison, A. (1996), Macroeconomic accounts for European countries, in: B. van Ark and N. F. R. Crafts (eds.), Quantitative aspects of postwar European economic growth, Cambridge, Cambridge University Press, pp. 27-83.

Maddison, A. (1997), The Nature and Functioning of European Capitalism: A Historical and Comparative Perspective, mimeo, Groningen Growth and Development Centre. 
Mankiw, N. G., D. Romer and D. Weil (1992), A Contribution to the Empirics of Economic Growth, Quarterly Journal of Economics, 107, n.2, pp. 407-438.

Matthews, R. C. O., C. H. Feinstein and J. Odling-Smee (1983), British Economic Growth, 1856-1973, Stanford, Stanford University Press.

Mauro, P. (1995), Corruption and Growth, Quarterly Journal of Economics, 110, n. 3 , pp. $681-712$.

Milbourne, R. (1995), Factor Convergence versus Productivity Convergence, paper presented to the 7th World Econometrics Congress, Tokyo.

Miller, M. and P. Luangaram (1998), Financial Crisis in East Asia: Bank Runs, Asset Bubbles and Antidotes, National Institute Economic Review, 165, 66-82.

Mills, T. C. and N. F. R. Crafts (1996), Trend Growth in British Industrial Output, 1700-1913: a Reappraisal, Explorations in Economic History, 33, n. 3, 277-295.

Mills, T. C. and N. F. R. Crafts (1999), After the Golden Age: A Long Run Perspective on Growth Rates that Speeded Up, Slowed Down and Still Differ, The Manchester School, forthcoming.

Mokyr, J. (1977), Demand versus Supply in the Industrial Revolution, Journal of Economic History, 37, n.4, 981-1008.

Mokyr, J. (1993), Introduction: the new economic history and the industrial revolution, in: J. Mokyr (ed.), The British industrial revolution: an economic perspective, Oxford, Westview Press, pp. 1-131.

Morrison, C. J. (1993), A Microeconomic Approach to the Measurement of Economic Performance, Berlin, Springer-Verlag.

Nelson, R. R. and G. Wright, The Rise and Fall of American Technological Leadership: the Postwar Era in Historical Perspective, Journal of Economic Literature, 30, n.4, pp. 1931-1964.

Nordhaus, W. D. and J. Tobin (1972), Is Growth Obsolete?, New York, Columbia University Press.

North, D. C. and Thomas, R. P. (1973), The Rise of the Western World: A New Economic History, Cambridge, Cambridge University Press.

O'Brien, P. (1977), The New Economic History of the Railways, London, Croom Helm. 
O'Rourke, K. H. and J. G. Williamson (1994), Late Nineteenth Century AngloAmerican Factor Price Convergence: were Hecksher and Ohlin Right?, Journal of Economic History, 54, n. 4, pp. 892-916.

O'Rourke, K. H. and J. G. Williamson (1995), Open Economy Forces and late Nineteenth Century Swedish Catch-Up, Scandinavian Economic History Review, 43, n. 1, 171-203.

Patel, P. and K. Pavitt (1992), The Innovative Performance of the World's Largest Firms: Some New Evidence, Economics of Innovation and New Technology, 2, n.1, pp. 91-102.

Phelps-Brown, E. H. (1977), The Inequality of Pay, Oxford, Oxford University Press.

Prescott, E.C. (1998), Needed a Theory of Total Factor Productivity, International Economic Review, 39, n.3, 525-551.

Preston, S.H. (1975), The changing relation between mortality and level of economic development, Population Studies, 29, n.2, 231-248.

Qizilbash, M. (1997), Pluralism and Well-Being Indices, World Development, 25, n. 12, pp. 2009-2026.

Rodrik, D. (1995), Getting Policy Interventions Right: How South Korea and Taiwan Grew Rich, Economic Policy, 20, pp. 55-107.

Rodrik, D. (1997), TFPG Controversies, Institutions and Economic Performance in East Asia, Centre for Economic Policy Research Discussion Paper n.1587.

Romer, P. M. (1993), Idea Gaps and Object Gaps in Economic Development, Journal of Monetary Economics, 32, n.3, pp. 543-573.

Rossi, N., A. Sorgato and G. Toniolo (1992), Italian Historical Statistics, 18901990, University of Venice Dipartimento di Scienze Economiche Working Paper n. 92-18.

Rossi, N, and G. Toniolo (1991), Catching Up or Falling Behind? Italy's Economic Growth, 1895-1947, Economic History Review, 45, n.3, pp. 537-563.

Rossi, N. and G. Toniolo (1996), Italy, in: N. F. R. Crafts and G. Toniolo (eds.), Economic growth in Europe since 1945, Cambridge, Cambridge University Press, pp. $427-454$. 
Rostow, W. W. (1960), The Stages of Economic Growth, Cambridge, Cambridge University Press.

Sandberg, L. G. (1981), The entrepreneur and technological change, in: R. C. Floud and D. N. McCloskey (eds.), The economic history of Britain since 1700, vol. 2, Cambridge, Cambridge University Press, pp. 99-120.

Shapiro, M. and D.Wilcox (1996), Mismeasurement in the Consumer Price Index, National Bureau of Economic Research Working Paper No. 5590.

Smith, H. (1995), Industry Policy in East Asia, Asian-Pacific Economic Literature, 9, n.1, pp. 17-39.

Steckel, R. H. (1983), Height and Per Capita Income, Historical Methods, 16, pp. $1-7$.

Steckel, R. H. (1992), Stature and living standards in the United States, in: R. E. Gallmann and J. J. Wallis (eds.), American economic growth and standards of living before the civil war, Chicago, University of Chicago Press, pp. 265-308.

Steckel, R. H. (1995), Stature and the Standard of Living, Journal of Economic Literature, 33, n.4, pp. 1903-1940

Steckel, R. H. and Floud, R. (1997), Conclusions, in: R. H. Steckel and R. Floud (eds.), Health and welfare during industrialization, Chicago, University of Chicago Press, pp. 423-449.

Szreter, S. (1997), Economic Growth, Disruption, Disease and Death: On the Importance of the Politics of Public Health for Development, Population and Development Review, 23, n.4, pp. 693-728.

Szreter, S. and G. Mooney, Urbanization, Mortality and the Standard of Living Debate: New Estimates of the Expectation of Life at Birth in Nineteenth Century British Cities, Economic History Review, 51, n.4, pp. 84-112.

Taylor, C. T. and D. A. Jodice (1983), World Handbook of Political and Social Indicators, New Haven, Yale University Press.

Usher, D. (1980), The Measurement of Economic Growth, Oxford, Blackwell.

Venables, A. J. and M. Gasiorek (1998), The Welfare Implications of Transport Improvements in the Presence of Market Failure, mimeo, DETR, London. 
Voth, H-J. (1998), Time and Work in Eighteenth Century London, Journal of Economic History, 58, n.1, pp. 29-58.

Wachter, K. W. and T. J. Trussell (1982), Estimating Historical Heights, Journal of the American Statistical Association, 77, n.2, pp. 277-293.

Wade. R. (1990), Governing the Market, Princeton, Princeton University Press.

Watkins, S. C. (1986), Conclusions, in: A. J. Coale and S. C. Watkins (eds.), The decline of fertility in Europe, Princeton, Princeton University Press, pp. 420-449.

Weingast, B. (1995), The Economic Role of Political Institutions: MarketPreserving Fiscal Federalism and Economic Development, Journal of Law, Economics, and Organization, 11, n.1, p. 1-31.

Williamson, J. G. (1984), British Mortality and the Value of Life, 1781-1931, Population Studies, 38, n.2, pp. 157-172.

Williamson, J. G. (1990), Coping with City Growth during the Industrial Revolution, Cambridge, Cambridge University Press.

Williamson, J. G. 91996), Globalization, Convergence, and History, Journal of Economic History, 56, n.2., pp. 277-306.

Wright, G. (1990), The Origins of American Industrial Success, 1879-1940, American Economic Review, 80, n.3, pp. 651-668.

Wrigley, E. A. and R. Schofield (1981), The Population History of England, 15411871, London, Arnold.

Young, A. (1995), The Tyranny of Numbers: Confronting the Statistical Realities of the East Asian Growth Experience, Quarterly Journal of Economics, 110, n.3, pp. 641-680. 


\section{LONDON SCHOOL OF ECONOMICS}

\section{ECONOMIC HISTORY DEPARTMENT WORKING PAPERS}

1992

1. Competing Notions of "Competition" in Late-Nineteenth Century American Economics

Mary S. Morgan

2. New Light Through Old Windows: A New Perspective on the British Economy in the Second World War

Peter Howlett

3. Social Risk and Social Welfare in Britain, 1870-1939

Paul Johnson

4. Textile Factories, Tuberculosis and the Quality of Life in Industrializing Japan

Janet Hunter

5. European Emigration 1815-1930. Looking at the Emigration Decision Again Dudley Baines

6. Scale Bias \& State Building: an Historical Perspective on Government Intervention, Political Systems \& Economic Performance in Tropical Africa Gareth Austin

7. Class Law in Victorian England Paul Johnson

8. The Instituto Nacional de Prevision Social and Social Insurance Reform in Argentina, 1944 to 1953

Peter Lloyd-Sherlock

9. Human Capital and Payment Systems in Britain, 1833-1914

Dudley Baines, Peter Howlett, Paul Johnson

10. Much Ado About Little

Robert Humphreys

11. Regional Fairs, Institutional Innovation and Economic Growth in Late Medieval Europe

S.R. Epstein 
12. The Performance of Public Enterprises in South Africa, Zambia and Zimbabwe during the last two decades

David Ferreira

13. Political Primacy in Economic Laws: A Comparison of British and American Anti-dumping Legislation, 1921

Peter M. Richards

14. Scientific Charity in Victorian London. Claims and Achievements of the Charity Organisation Society, 1869-1890

Robert Humphreys

15. Essex Men Vindicated: Output, Incomes and Investment in Agriculture, 1850-73

E.H. Hunt and S.J. Pam

1994

16. Learning by Doing among Victorian Farmworkers: A case study in the Biological and Cognitive Foundations of Skill Acquisition David Mitch

17. "Blind Alley" Employment and the Role of Adolescent Labor Force Experience in Skill Development in Late 19th and Early 20th Century England

David Mitch

18. British Imperialism in Microcosm: The Annexation of the Cocos (Keeling) Islands Margaret Ackrill

19. Short-termism on Trial: An Empirical Approach Breht Feigh

20. Tenancy and Agricultural Techniques: Evidence from the 1882 Commission David Coombs

21. Economic Distress and Unemployment in Australia since 1850 Paul Johnson

22. Freedom and Growth. The European Miracle?

S.R. Epstein 
23. Bygone Charity - Myths and Realities

Robert Humphreys

24. Late Economic Development in a Regional Context

Domingos Giroletti, Max-Stephan Schulze, Carles Sudrià

1995

25. How Important was Tariff Protection for Spanish Farming prior to 1936?

James Simpson

26. British Business in Argentina

Colin M. Lewis

27. The Principal-Agent Question: the Chartered Trading Companies

S.P. Ville and S.R.H. Jones

28. Craft Guilds, Apprenticeship and Technological Change in Pre-Modern

Europe

S.R. Epstein

29. The 'Quality of Life': Lessons for and from the British Industrial Revolution N.F.R. Crafts

1996

30. Transplanting Economic Ideas: International Coercion and Native Policy Ioanna Pepelasis Minoglou

31. Creditors, Debtors and the Law in Victorian and Edwardian England Paul Johnson

32. Population Growth and the Dynamics of Canadian Development: A Multivariate Time Series Approach Alan G. Green and Gordon R. Sparks

33. The Human Development Index: Some Historical Comparisons N.F.R. Crafts

34. The Character of "Rational Economic Man" Mary S. Morgan 
35. Were British "Business Cycles" Cyclical? Evidence from Historical Statistics, 1700-1913

Philip Epstein

36. Re-Estimating Austrian GDP, 1870-1913: Methods and Sources Max-Stephan Schulze

37. The labour force participation and economic well-being of older men in London, 1929-31

Dudley Baines and Paul Johnson

38. 'Pawns will live when slaves is apt to dye': Credit, Slaving and Pawnship at Old Calabar in the era of the Slave Trade

Paul E. Lovejoy and David Richardson

1998

39. The Abolition of Resale Price Maintenance in Britain in 1964: a turning point for British Manufacturers?

Helen Mercer

40. American Business Cycles since World War II: Historical Behaviour and Statistical Representation

Philip Epstein

41. Finance Capital in the Weimar Republic: Does evidence on supervisory board representation support Hilferding's view of the role of large banks in German capitalism?

Jeroen F. De Boer

42. Productivity Growth during the First Industrial Revolution: Inferences from the Pattern of British External Trade

C. Knick Harley and N.F.R. Crafts

43. Clogs to Clogs in Three Generations? Explaining Entrepreneurial Performance in Britain since 1850

Tom Nicholas

44. Industrial Growth in the Third World, c.1870-c.1990: Depressions, IntraRegional Trade, and Ethnic Networks Edited by Gareth Austin 
45. In search of the 'traditional' working class: social mobility and occupational continuity in inter-war London

Dudley Baines and Paul Johnson

46. The late medieval crisis as an 'integration crisis'

S.R. Epstein

1999

47. The Impact of American Aid in the Spanish Economy in the 1950s Oscar Calvo-Gonzalez

48. Quantitative Economic History

N.F.R. Crafts 




